\title{
Creditors Attitude towards Clients Sustainability Reporting Practices in India
}

\author{
Bandaru Venugopal \\ Assistant Professor, Indian Institute of Plantation Management Bengaluru, Bangalore -560056, INDIA \\ *E-mail for correspondence: vgopal.phd@gmail.com
}

https://doi.org/10.18034/abr.v9i3.339

\begin{abstract}
The research is aimed at "To evolve a method of sustainability reporting practices for social expenditure incurred by business organizations so that the information to the creditor and stakeholders becomes "impact measurable" thereby, becomes more meaningful \& relevant. "Since sustainability reporting practices are getting more \& more adopted by many companies there is a great need to come out with an appropriate method for reporting which may cover quantitative \& qualitative aspects \& also measure the impact of such contribution. In contrast to financial reporting, the history of sustainability reporting (SR) is comparatively recent. The proposition that organizations, and business organizations in particular, should supplement their financial accounting with accounting on their environmental, social and other 'non-financial' performance - or 'sustainability reporting'. Responding to the increasing media attention to environmental problems, most reports focused on environmental policies and performance. This present research paper attempts to evaluate the Creditors' participation in framing sustainability reporting practices in India. Result Mean weighted score towards awareness on sustainable reporting practices (SRP) of their clients is 3.71, i.e.74.2 percent level of awareness that provides satisfaction on their client's repayment terms to the extent of 3.10 score or 62 percent only. Therefore, it can be concluded that the impact of sustainable reporting practices of SENSEX companies on their creditors' terms is significant statistically. Hence, it is suggested to the creditors to examine the variables (such as ASRP, PSA, and SDI) which have a negative impact on the creditors and further it should improve the variables (CEPCD, CSSR, G, AG \& Q) which have a positive impact but not significant statistically.
\end{abstract}

Key words: Creditors, Corporates, Sustainability Reports, Environment, Disclosure Practices

\section{INTRODUCTION}

The economic activities of corporate entities in different countries are causing concerns for planners, managers and the environmentally conscious people. Since the corporations continue to be the biggest consumers of environmental resources and hence they should shoulder greater responsibilities towards the environmental management. There is a pressing need to ensure that environmental concerns are woven into corporate actions and the best corporate governance practices. It is now being realized by the economists, environmentalists, business managers and accountants that (i) if the benefits from rising incomes are offset by the costs imposed on the health and quality of life from pollution, this cannot be called development and that (ii) environmental damage can undermine future productivity. The corporate managers also need to remember the effects of their investment decisions on the environment.

The Importance of sustaining the environment and the urgency of the situation cannot be disregarded in today's era of environmental concerns and global warming. Most of the companies are becoming conscious of the impact of their operations on environmental and are making policies to demonstrate the company's commitment towards mitigation of its direct and indirect environmental impacts. Many actions include planning their facilities in an environment-friendly manner, leaving a minimal footprint on the neighboring environment, minimizing the destruction of natural areas, habitants, bio- diversity and reducing soil loss in and around the campuses, while at the same time some are being more energy-efficient and pollution-free. No doubt, in the 
context of fast developing nations like India and China heightened economic activity with rapid urbanization, increasing disposable income and higher standard of living, this has exerted massive pressure on the natural and environmental resources available in these countries. Concerns for a sustainable economy and a clean environment have increased and given rise to policies and strong political will towards the development of sustainable energy sources. The challenge in current timing is achieving a sustainable balance between environmental management and economic growth.

The corporations in the developed economies closely link their performance with the extent, quality and timeliness of environmental disclosure. The increasing trend towards liberalization and globalization demands increased integration and the convergence to global environment reporting and accounting standards. Therefore it is not only important for the companies to be transparent, accountable and socially responsible but also to ensure adequate returns to the shareholders and satisfy various stakeholders and society at large about their conduct.

\section{REVIEW OF LITERATURE}

Haigh and Shapiro (2011) researched upon the significance of carbon emissions reporting in case of in the investment banking industry in the USA, Europe and Australia. Desk research was used to survey the Functionaries at selected financial institutions were surveyed. A non-state actor Climate Disclosure Standards Board for general-purpose carbon emissions reporting was assessed. The study focused upon the place, content, and style of reporting, and used a functional perspective of decision usefulness. It was interesting to find that heavier polluters as superior "carbon performers" (the imaginary), while reported variations in industrial carbon emissions levels have been ignored in asset allocation decisions (the actual). Exclusion of carbon emissions in constructions of firm value; diverse methods used by firms to calculate, measure and report carbon emissions; the appropriate venue for such reporting; and the quantum of data have been identified as the main four factors impacting Environmental investing.

Cormier et al. (2011) explained that social disclosure and environmental disclosure substitute each other in reducing stock market asymmetry. Where social disclosure has been found to reinforce the in formativeness of environmental disclosure for stock markets and in some condition it also substituted the information on environment. The authors also suggested that stakeholders must assess and retain an increasing flow of information.

Rao et al. (2012) analyzed 2008 annual reports of largest 100 Australian firms listed on the Australian Stock Exchange (ASX) to determine the amount of environmental reporting. Through quantitative analysis a significant positive relationship between the extent of Environmental Reporting and the proportions of independent and female directors on a board has been established. The extent of Environmental Reporting and institutional investors and board size also found a positive relationship.

Tien-Shang (2012) analyzed through use of a mail survey data in Taiwan and structural equation modeling that instrumental motives and political motives have direct influence upon the environmental performance. It has also been found that instrumental motives had marginal effects on both cooperate environmental responsibility and environmental performance. The marginal effects of political motives on environmental performance have also been reflected. It was revealed that the corporate environmental responsibly is a pivot in these cause-effect relationships.

Giovanni (2012) examined and reported upon the effect of both internal and external environmental management (EM) on the triple bottom line (TBL). TBL includes all three types of environmental, economic, and social performances. The researchers found that internal EM is a successful driver of TBL. Environmental and social performance is enhanced by external environmental management. External EM is a less effective driver, contributing only positively to environmental performance and exerting only an indirect, marginal impact on economic performance. TBL is directly and positively impacted by TBL internal environmental management. The study suggested that corporate top management need to focus their efforts on internal EM, as it is found to be more effective than external EM.

Amran and Keat Ooi (2014) illustrated the emerging trend and significance of sustainability reporting, and suggested that stakeholders' participation assistances gain insights into this escalating development to better understand stakeholder concerns. The researchers were able to find from their study that, pressure from stakeholder forces businesses to ascertain their governance, efficiency, accountability and transparency through corporate sustainability disclosure. To satisfy diverse stakeholders 'necessities and attain continuous perfection, it is important that businesses involve with targeted stakeholders and attain significant response to their sustainability performance and reporting processes, which helps to meet stakeholders' demands and increases businesses' future sustainability agenda.

Jain and Winner (2016) conducted a study on "CSR and sustainability reporting practices of top companies in India." The purpose of the study was to contribute an international viewpoint to corporate social responsibility and sustainability thoughts by exploring CSR/Sustainability reporting practices of the 200 biggest state-owned and private companies in India. For doing 
the study, the researchers conducted a study at the Danish carpet manufacturer EGE. The researchers infer the case from the standpoint of rational constructivism, which focuses on the combination of four magnitudes: possibilities, facts, values, and communication. This study provides a clear picture of how corporations in developing and divergent economy, such as India are suppose roles of corporate citizens and are vigorously using web-based communication to engage and intermingle with stakeholders on issues that are of general concern.

\section{SigNIFICANCE OF THE STUDY}

Indian Economy is developing at a rapid pace like never before. Sustainable development is the key to an organization's success, because only sustainable development can provide long term holistic benefits to current and future generations. The current study will help organizations understand the importance of stakeholder engagement in the reporting process.

In regard to Environmental benefits, a sustainable organization will replenish back to nature whatever has been utilized in the form of natural resources. Hence the Ecological balance is maintained for future generations. In regard to Social benefits, the quality of the work force is improved. This will obviously result in the improved productivity of an organization. A satisfied stakeholder will certainly add value to the organization. The objectives of the study is to evaluate the Creditors participation in framing sustainability reporting guidelines

\section{Methodology}

\section{Data Collection}

The present study is mainly based on two sources of data

- The primary data includes data collected through questionnaires and interviews.

- Secondary data comprises of data collected from research articles, journals, websites, newspapers, etc

\section{Analysis of Data}

Inputs

- Questionnaire Feedback

- Secondary data input

Process

- The data collected has been primarily tabulated and master table was prepared

- Percentage analysis has been the basic tool for analysis

- $\quad$ Further MS Excel - SPSS package have been used for analyzing the data

- Statistical tools for data analysis
The primary data was analyze using the statistical packages for social sciences (SPSS - 20.0 version).

\section{Period of study}

The primary data relates to the period from May 2016 to Feb 2017. Structured questionnaire was administered on creditors during the period.

\section{Sampling Plan}

The sample required for the study comprises of the data collected from BSE 30 Companies. The sample size is 100 (Creditors - 100).

\section{Sample Profile}

\begin{tabular}{|l|c|c|}
\hline Sector & Companies & Creditors \\
\hline Manufacturing/Mining & 13 & 41 \\
Telecom & 2 & 6 \\
Banking & 3 & 11 \\
Information \& Communication & 3 & 11 \\
Consumer Goods Companies & 3 & 10 \\
Infrastructure & 4 & 13 \\
Pharma & 2 & 8 \\
\hline Total & $\mathbf{1 0 0}$ \\
\hline
\end{tabular}

\section{INTERPRETATION AND RESULTS}

\section{Correlation Analysis}

Correlation is the association or relationship between variables. The Pearson coefficient of correlation varies from -1 to +1 . If coefficient of correlation is 1 indicates that there is perfect positive association or relationship between variables and if coefficient of correlation is -1 indicates that there is perfect negative association or relationship between variables.

Table 1: Correlation $\mathrm{b} / \mathrm{w}$ Awareness of SRP and Repayment Terms of Clients

\begin{tabular}{|l|l|c|c|}
\hline \multicolumn{2}{|c|}{ Variables } & ASRP & CSRT \\
\hline \multirow{2}{*}{$\begin{array}{l}\text { ASRP of } \\
\text { Creditors }\end{array}$} & Pearson Correlation & 1 & $-.156^{\mathrm{NS}}$ \\
\cline { 2 - 4 } & Sig. (2-tailed) & & .122 \\
\hline \multirow{3}{*}{ CSRT } & Pearson Correlation & $-.156^{\mathrm{NS}}$ & 1 \\
\cline { 2 - 4 } & Sig. (2-tailed) & .122 & \\
\cline { 2 - 4 } & $\mathrm{N}$ & 100 & 100 \\
\hline
\end{tabular}

Source: Primary data and SPSS.

Note 1: NS not Significant at 1 percent level of significance

Note 2: Awareness of Sustainable Reporting Practices (ASRP) \& Creditors Satisfaction with Repayment Terms of Clients (CSRT)

Ho: There is no significant relationship between creditors' awareness of sustainable reporting practices and repayment terms of clients.

$\mathrm{H}_{1}$ : There is a significant relationship between creditors' awareness of sustainable reporting practices and repayment terms of clients. 
Table 1: shows that there is a negative correlation between creditor's awareness of sustainable reporting practices and the repayment terms of clients and its magnitude of correlation coefficient is -0.156 . To test the above hypothesis Pearson correlation is applied. The two tail significant level of $\mathrm{p}=0.122$ which is more than 0.01 . H1 is rejected and hence $\mathrm{H}_{0}$ is accepted at 1 percent of level of significance. It is observed that the statistically insignificant negative relationship between creditor's awareness of sustainable reporting practices and repayment terms of client's. It is concluded that if creditor's awareness of sustainable reporting practices increases then their satisfaction with the repayment terms of clients also decreases. The creditor's awareness of sustainable reporting practices is negatively correlated with the repayment terms of clients which is statistically insignificant at 1 percent level of significance. Therefore, it is suggested to the creditors to improve their awareness level towards the sustainable reporting practices of their clients to the optimum level so that it provides optimum satisfaction with regard to repayment terms of clients.

Table 2: Correlation b/w CCEPCD and Repayment Terms of Clients

\begin{tabular}{|l|l|c|c|}
\hline \multicolumn{2}{|c|}{ Variables } & CCEPCD & CSRT \\
\hline \multirow{2}{*}{ CCEPCD } & Pearson Correlation & 1 & $0.266^{* *}$ \\
\cline { 2 - 4 } & Sig. (2-tailed) & & .007 \\
\hline \multirow{3}{*}{ CSRT } & Pearson Correlation & $0.266^{* *}$ & 1 \\
\cline { 2 - 4 } & Sig. (2-tailed) & .007 & \\
\cline { 2 - 4 } & $\mathrm{N}$ & 100 & 100 \\
\hline
\end{tabular}

Source: Primary data and SPSS.

Note 1: ** Significant at 1 percent level of significance.

Note 2: Creditors Convinced with Existing Pollution Control Devices (CCEPCD) \& Creditors Satisfaction with Repayment Terms of Clients (CSRT).

$H_{\circ}$ : There is no significant relationship between creditors' Convinced with Existing Pollution Control Devices and repayment terms of clients.

$\mathrm{H}_{1}$ : There is a significant relationship between creditors' Convinced with Existing Pollution Control Devices and repayment terms of clients.

Table 2 shows that there is a positive correlation between creditor's Convinced with Existing Pollution Control Devices and the repayment terms of clients and its magnitude of correlation coefficient is 0.266 . To test the above hypothesis Pearson correlation is applied. The two tail significant level of $\mathrm{p}=0.007$ which is less than 0.01 . Ho is rejected and hence $H_{1}$ is accepted at 1 percent of level of significance. It is observed that the statistically significant positive relationship between creditors's convinced with Existing Pollution Control Devices and repayment terms of clients .It is concluded that if creditor's convinced with Existing Pollution Control Devices increases then their satisfaction with the repayment terms of clients also increases. The creditors convinced with Existing Pollution Control Devices is positively correlated with the repayment terms of clients which is statistically significant at 1 percent level of significance. Therefore, it is suggested to the managements of SENSEX companies to improve creditors convinced with Existing Pollution Control Devices to the optimum level so that it leads to satisfaction with regard to repayment terms of clients.

Table 3: Correlation b/w CPSA and Repayment Terms of Clients

\begin{tabular}{|l|l|c|c|}
\hline \multicolumn{2}{|c|}{ Variables } & CPSA & CSRT \\
\hline \multirow{4}{*}{ CPSA } & Pearson Correlation & 1 & -0.100 \\
\cline { 2 - 4 } & Sig. (2-tailed) & & .320 \\
\hline \multirow{3}{*}{ CSRT } & Pearson Correlation & -0.100 & 1 \\
\cline { 2 - 4 } & Sig. (2-tailed) & .320 & \\
\cline { 2 - 4 } & N & 100 & 100 \\
\hline
\end{tabular}

Source: Primary data and SPSS.

Note 1: ${ }^{* *}$ Significant at 1 percent level of significance.

Note 2: Creditors Participation in Sustainable Activities (CPSA) \& Creditors Satisfaction with Repayment Terms of Clients (CSRT)

Ho: There is no significant relationship between creditors' Participation in Sustainable Activities and repayment terms of clients.

$\mathrm{H}_{1}$ : There is a significant relationship between Creditors' Participation in Sustainable Activities and repayment terms of clients.

Table 3 describes that there is a negative correlation between creditor's participation in sustainable activities and the repayment terms of clients and its magnitude of correlation coefficient is -0.100 . To test the above hypothesis Pearson correlation is applied. The two tail significant level of $\mathrm{p}=0.320$ which is more than 0.01 . $\mathrm{H} 1$ is rejected and hence $\mathrm{H}_{0}$ is accepted at 1 percent of level of significance. It is observed that the statistically insignificant negative relationship between Creditor's Participation in Sustainable Activities and repayment terms of client's. The creditor's Participation in Sustainable Activities is negatively correlated with the repayment terms of clients which is statistically insignificant at 1 percent level of significance. Therefore, it is suggested that creditors should maintain optimum level of participation in sustainable activities reporting practices of their clients so that it provides optimum satisfaction with regard to repayment terms of clients.

Table 4: Correlation b/w Liquidity Ratio (LR) and Repayment Terms of Clients

\begin{tabular}{|l|l|c|c|}
\hline \multicolumn{2}{|c|}{ Variables } & LR & CSRT \\
\hline \multirow{2}{*}{ LR of clients } & Pearson Correlation & 1 & $.571^{* *}$ \\
\cline { 2 - 4 } & Sig. (2-tailed) & & .000 \\
\hline \multirow{4}{*}{ CSRT } & Pearson Correlation & $.571^{* *}$ & 1 \\
\cline { 2 - 4 } & Sig. (2-tailed) & .000 & \\
\cline { 2 - 4 } & $\mathrm{N}$ & 100 & 100 \\
\hline
\end{tabular}

Source: Primary data and SPSS. 
Note 1: ** Significant at 1 percent level of significance

Note 2: Creditors Satisfaction with Repayment Terms of Clients (CSRT)

Ho: There is no significant relationship between creditors' satisfaction with liquidity and repayment terms of clients.

$\mathrm{H}_{1}$ : There is a significant relationship between creditors' satisfaction with liquidity and repayment terms of clients.

Table 4 shows that there is a positive correlation between creditor's satisfaction with liquidity and the repayment terms of clients and its magnitude of correlation coefficient is 0.571 . To test the above hypothesis Pearson correlation is applied. The two tail significant level of $p$ $=0.000$ which is less than 0.01 . Ho is rejected and hence $\mathrm{H}_{1}$ is accepted at 1 percent of level of significance. It is observed that the statistically significant positive relationship between creditor's satisfaction with liquidity ratio and repayment terms of clients .It is concluded that if creditor's satisfaction with liquidity increases then their satisfaction with the repayment terms of clients also increases. The creditor's satisfaction with liquidity of clients is positively correlated with the repayment terms of clients which is statistically significant at 1 percent level of significance. Therefore, it is suggested to the creditors to observe the liquidity ratio of their clients and insist them to maintain optimum liquidity so that it leads to satisfaction with regard to repayment terms of clients.

Table 5: Correlation B/W Solvency Ratio's (SR) and Repayment Terms of Clients

\begin{tabular}{|l|l|c|c|}
\hline \multicolumn{2}{|c|}{ Variables } & LR & CSRT \\
\hline $\begin{array}{l}\text { Solvency } \\
\text { Ratio's }\end{array}$ & Pearson Correlation & 1 & $.477^{* *}$ \\
\cline { 2 - 4 } & Sig. (2-tailed) & & .000 \\
\hline \multirow{4}{*}{ CSRT } & Pearson Correlation & $.477^{* *}$ & 1 \\
\cline { 2 - 4 } & Sig. (2-tailed) & .000 & \\
\cline { 2 - 4 } & \multicolumn{1}{|c}{$\mathrm{N}$} & 100 & 100 \\
\hline
\end{tabular}

Source: Primary data and SPSS.

Note 1: ${ }^{* *}$ Correlation is significant at the 0.01 level (2tailed).

Note 2: Creditors Satisfaction with Repayment Terms of Clients (CSRT)

$\mathrm{H}_{\mathrm{o}}$ : There is no significant relationship between creditors' satisfaction with solvency ratios and repayment terms of clients.

$\mathrm{H}_{1}$ : There is a significant relationship between creditors' satisfaction with solvency ratios and repayment terms of clients.

Table 5 shows that there is a positive correlation between creditor's satisfaction with solvency ratios and the repayment terms of clients and its magnitude of correlation coefficient is 0.477. To test the above hypothesis Pearson correlation is applied. The two tail significant level of $p=0.000$ which is less than 0.01 . Ho is rejected and hence $H_{1}$ is accepted at 1 percent of level of significance. It is observed that the statistically significant positive relationship between creditor's satisfaction with solvency ratios and repayment terms of clients' .It is concluded that if creditor's satisfaction with solvency ratios increases then their satisfaction with the repayment terms of clients also increases. The creditor's satisfaction with solvency ratios of clients is positively correlated with the repayment terms of clients which is statistically significant at 1 percent level of significance. Therefore, it is suggested to the creditors to observe the solvency ratios of their clients and insist them to maintain optimum levels so that it leads to satisfaction with regard to repayment terms of clients.

Table 6: Correlation b/w Strategic Decisions Intimation and CSRT

\begin{tabular}{|l|l|c|c|}
\hline Variables & $\begin{array}{c}\text { Strategic } \\
\text { Decisions } \\
\text { Intimation }\end{array}$ & CSRT \\
\hline $\begin{array}{l}\text { Strategic } \\
\text { Decisions } \\
\text { Intimation }\end{array}$ & Pearson Correlation & 1 & -.189 \\
\cline { 2 - 4 } & Sig. (2-tailed) & & .060 \\
\cline { 2 - 4 } & $\mathrm{N}$ & 100 & 100 \\
\hline CSRT & Pearson Correlation & -.189 & 1 \\
\cline { 2 - 4 } & Sig. (2-tailed) & .060 & \\
\cline { 2 - 4 } & $\mathrm{N}$ & 100 & 100 \\
\hline
\end{tabular}

Source: Primary data and SPSS.

Note 1: ${ }^{* *}$ Correlation is significant at the 0.01 level (2-tailed).

Note 2: Creditors Satisfaction with Repayment Terms of Clients (CSRT)

Ho: There is no significant relationship between strategic decision intimation by clients and repayment terms of clients.

$\mathrm{H}_{1}$ : There is a significant relationship between strategic decision intimation by clients and repayment terms of clients.

Table 6 describes that there is a negative correlation between strategic decision intimation by clients and the repayment terms of clients and its magnitude of correlation coefficient is -0.189 . To test the above hypothesis Pearson correlation is applied. The two tail significant level of $\mathrm{p}=0.060$ which is more than 0.01 . $\mathrm{H} 1$ is rejected and hence $\mathrm{H}_{0}$ is accepted at 1 percent of level of significance. It is observed that the statistically insignificant negative relationship between strategic decision intimation by clients and repayment terms of client's. The creditor's strategic decision intimation by clients is negatively correlated with the repayment terms of clients which is statistically insignificant at 1 percent level of significance. Therefore, it is suggested to the managements of SENSEX companies that creditors should be intimated about the clients' strategic decisions frequently so that it provides optimum satisfaction with regard to repayment terms of clients. 
Table 7: Creditors Opinion towards their Clients Sustainability Reporting Practices

\begin{tabular}{|c|c|c|c|c|c|}
\hline S.No & Creditor's Opinion & $\begin{array}{l}\text { Weighted } \\
\text { Mean Score }\end{array}$ & $\begin{array}{c}\text { Std. } \\
\text { Deviation }\end{array}$ & Chi-Square test at 9 d.f & Result \\
\hline 1 & Awareness of SRP & 3.71 & .79512 & $\begin{array}{l}\text { Chi -Square Value }=19.15 \\
\& \mathrm{p}=0.024^{*}\end{array}$ & \multirow{6}{*}{$\begin{array}{l}\text { All alternative hypotheses } \\
\text { such as } \mathrm{H}_{1}, \mathrm{H}_{2}, \\
\qquad \mathrm{H}_{3} . \mathrm{H}_{4}, \mathrm{H}_{5} \& \mathrm{H}_{6} \\
\text { are accepted but all null } \\
\text { hypotheses are rejected. }\end{array}$} \\
\hline 2 & $\begin{array}{l}\text { Convinced with Existing } \\
\text { Pollution Control Devices }\end{array}$ & 3.50 & .65905 & $\begin{array}{l}\text { Chi }- \text { Square Value }=31.80 \\
\& p=0.000^{*}\end{array}$ & \\
\hline 3 & $\begin{array}{l}\text { Participation of } \\
\text { Sustainable Activities }\end{array}$ & 3.88 & .76910 & $\begin{array}{l}\text { Chi-Square Value }=31.05 \\
\& \mathrm{p}=0.000^{*}\end{array}$ & \\
\hline 4 & $\begin{array}{l}\text { Satisfaction with Liquidity } \\
\text { Ratios }\end{array}$ & 3.15 & .86894 & $\begin{array}{l}\text { Chi-Square Value }=56.79 \\
\& p=0.000^{*}\end{array}$ & \\
\hline 5 & $\begin{array}{l}\text { Satisfaction with Solvency } \\
\text { Ratios }\end{array}$ & 3.20 & .92113 & $\begin{array}{l}\text { Chi-Square Value }=64.04 \\
\& p=0.000^{*}\end{array}$ & \\
\hline 6 & $\begin{array}{l}\text { Strategic Decisions } \\
\text { Intimation }\end{array}$ & 3.86 & .58638 & $\begin{array}{l}\text { Chi-Square Value }=22.85 \\
\& p=0.007^{*}\end{array}$ & \\
\hline 7 & $\begin{array}{l}\text { Satisfaction with } \\
\text { Repayment Terms of Firms }\end{array}$ & 3.10 & 1.15032 & & \\
\hline
\end{tabular}

Source: Primary data and SPSS.

Note: * Statistically Significant at 5 percent level of significance.

\section{Null Hypotheses}

H01: Influence of Creditor's Awareness in Sustainable Activities on their Satisfaction with Repayment terms by their firms is not significant statistically.

$\mathrm{H}_{02}: \quad$ Influence of Creditor's convinced with existing pollution control devices on their Satisfaction with Repayment terms by their firms is not significant statistically.

$\mathrm{H}_{03}$ : Influence of Creditor's Participation in Sustainable Activities on their Satisfaction with Repayment terms by their firms is not significant statistically.

$\mathrm{H}_{04}$ : Influence of Creditor's satisfaction with liquidity ratios on their Satisfaction with Repayment terms by their firms is not significant statistically.

Hos: Influence of Creditor's satisfaction with solvency ratios on their Satisfaction with Repayment terms by their firms is not significant statistically.

$\mathrm{H}_{06}$ Influence of Creditor's intimation of strategic decisions on their Satisfaction with Repayment terms by their firms is not significant statistically

\section{Alternative Hypotheses}

$\mathrm{H}_{1}$ : Influence of Creditor's Awareness in Sustainable Activities on their Satisfaction with Repayment terms by their firms is significant statistically.

$\mathrm{H}_{2}$ : Influence of Creditor's convinced with existing pollution control devices on their Satisfaction with Repayment terms by their firms are significant statistically.

$\mathrm{H}_{3}$ : Influence of Creditor's Participation in Sustainable Activities on their Satisfaction with
Repayment terms by their firms is significant statistically.

$\mathrm{H}_{4}: \quad$ Influence of Creditor's satisfaction with liquidity ratios on their Satisfaction with Repayment terms by their firms is significant statistically.

$\mathrm{H}_{5}$ : Influence of Creditor's satisfaction with solvency ratios on their Satisfaction with Repayment terms by their firms is significant statistically.

$\mathrm{H}_{6}$ : Influence of Creditor's intimation of strategic decisions on their Satisfaction with Repayment terms by their firms is significant statistically

Table 7 indicates that creditors opinioned that their mean weighted score towards awareness on sustainable reporting practices (SRP) of their clients is 3.71, i.e.74.2 percent level of awareness that provides satisfaction on their client's repayment terms to the extent of 3.10 score or 62 percent only. It also reveals that creditors awareness towards their clients SRP enhances then their satisfaction level of clients repayment terms also increased. Moreover, it is proved statistically also that Influence of Creditor's awareness in sustainable activities on their satisfaction with repayment terms by their clients is significant statistically at 5 percent level of significance as chi-square value $=19.15$ at 9 degrees of freedom $(\mathrm{d} \mathrm{f})$ with significant value of $p=0.024<0.05$. Ho1 is rejected and hence H1 is accepted. Therefore it is observed that 74.2 percent of creditors awareness towards their client's sustainable reporting practices provides satisfaction level to the extent of 62 percent only due to lacking of awareness in clients SRP to the extent of 25.8 percent. It is concluded that there is a statistically significant association between creditors awareness level in their clients Sustainable Reporting Practices and Satisfaction with repayment terms of clients. The influence of creditor's awareness level in their SRP on 
their satisfaction with repayment terms of clients is significant statistically. Hence, it is suggested to creditors to improve their awareness level in their client's sustainable reporting practices (SRP) so that to have maximum satisfaction level on their client's repayment terms which creates win-win situation for both the players in terms of sustainable development.

\section{Conclusion}

The research is aimed at "To evolve a method of sustainability reporting practices for social expenditure incurred by business organizations so that the information to the creditor and stakeholders becomes "impact measurable" thereby, becomes more meaningful \& relevant. This research paper focuses on evaluate the creditors participation in framing sustainable reporting with to examine the variables Satisfied with the repayment Terms of the company, Part of the sustainability activities of the Company, Aware of the sustainability reporting practices of the organization, Convinced with the existing pollution control devices, Company intimates the creditors regarding strategic Decisions affecting their interest, Satisfied with the solvency ratios of the Company, Satisfied with the liquidity ratios of the Company.

Therefore, it can be concluded that the impact of sustainable reporting practices of SENSEX companies on their creditors' terms is significant statistically. Hence, it is suggested to the creditors to examine the variables (such as ASRP, PSA and SDI) which have negative impact on the creditors and further it should improve the variables (CEPCD, CSSR, G, AG \& Q) which have positive impact but not significant statistically.

\section{REFERENCES}

Amran, A., and Keat Ooi, S. (2014). Sustainability reporting: meeting stakeholder demands. Strategic Direction, 30(7), 3841. doi: doi:10.1108/SD-03-2014-0035

Cormier, D., Ledoux, M., and Magnan M. (2011) "The informational contribution of social and environmental disclosures for investors", Management Decision, Vol. 49 No.8, pp.1276 - 1304

Giovanni, P. D. (2012) "Do internal and external environmental management contribute to the triple bottom line?" International Journal of Operations \& Production Management, Vol. 32 No.3, pp. 265 - 290.

Haigh Matthew, Shapiro, Matthew A., (2011) "Carbon reporting: does it matter?" Accounting, Auditing \& Accountability Journal, Vol. 25 No.1, pp.105 - 125.

Jain, R., \& Winner, L. H. (2016). CSR and sustainability reporting practices of top companies in India. Corporate Communications: An International Journal, 21(1), 36-55. doi: doi:10.1108/CCIJ-09-2014-0061

Tien-Shang, L. L. (2012) "The Pivotal Roles of Corporate Environment Responsibility", Industrial Management \& Data Systems, Vol. 112 No. 3, pp. $466-483$.

Rao, K. K., Tilt, C. A., and Lester, L. H. (2012) "Corporate Governance and Environmental Reporting: An Australian Study", Corporate Governance, Vol. 12 No. 2, pp.143 - 163. 
Online Archive: https://abc.us.org/ojs/index.php/abr/issue/archive 